\title{
Attempts to Explain the Variability in the Cation- Exchange Capacity of Soils in Terms of Particle Size and Organic-Matter Levels
}

\author{
M. A. Lugo-López and Raúl Pérez-Escolar ${ }^{1}$
}

\section{INTRODUCTION}

Cation exchange capacity is a very significant soil parameter. It can be defined as the ability of a soll to hold cations in readily available form. It is considered as perhaps the most important single measurement of the fertility potential of soils. There are various methods used for the determination of cation exchange capacity, but all of them are rather laborious and must be performed by expert technicians. Thus, there is need either for the development of simpler direct measuring techniques or of indirect methods to approximate cation exchange capacity values.

Furthermore, considerable variability in cation exchange capacity has been observed in what can be considered as similar soils. Usually this variability is attributed to variations in particle size distribution, clay minerals and organic matter content. However, such explanations are not always satisfactory. Thus, this paper reports on attempts to explain this variability mathematically in terms of particle size and organic matter content. The hypothesis tested postulated that variations in cation exchange capacity were directly related to the percentage of particles smaller than 0.05 and $0.002 \mathrm{~mm}$, and to the organic-matter percentage. If a single or a multiple correlation could have been proved valid, then by simple laboratory determinations and calculations an indirect method to predict cation exchange capacity values would be available.

\section{THE SOILS USED IN THIS STUDY}

The data for this study were taken from a group of soils from the Lajas Valley, in southwestern Puerto Rico (2). ${ }^{2}$ In general, the major soils of the Lajas Valley floor are very deep with a strikingly high, almost uniform, clay content of the expanding-lattice types; predominantly small pores; very slow hydraulic conductivity in the subsoils and very low aggregate stability below the surface layer. They are relatively low in organic matter and nitrogen and generally high in soluble salts and exchangeable sodium, which increases with depth (7).

1 Soil Scientist and Associate Soil Scientist, respectively, Agricultural Experiment Station, Mayagüez Campus, University of Puerto Rico, Río Piedras, P. R. Appreciation is expressed to Dr. B. G. Capo, Technical Consultant and to Mr. Mariano Antoni, Research Assistant in Statistics, for their valuable help and advice.

2 Italic numbers in parenthesis refer to Literature Cited, pp. 372-3. 
According to Carter (2) there are five soil associations as follows:

1. Moderately well drained to poorly drained, nearly level to sloping, calcareous alluvial soils.

2. Moderately well drained to poorly drained, nearly level, saline alkali and nonsaline alluvial soils. -

3. Well drained to excessively drained, level to sloping, sandy soils.

4. Steep soils on mountainsides, strongly sloping soils on foot hills, and soils in narrow to fairly wide valleys.

5. Steep soils on mountainsides, strongly sloping soils on foot slopes, and soils in narrow valleys and on fairly wide alluvial fans.

\section{PROCEDURE}

The original data for this work were obtained at the Soil Survey Laboratory, Soil Conservation Service, Lincoln, Nebr. (2). In the particle-size determination, the fine material (smaller than $0.05 \mathrm{~mm}$.) was analyzed by the pipette method. Organic matter was determined by acid dichromate digestion, $\mathrm{FeSO}_{4}$ titration. Cation exchange capacity was determined by the ammonium acetate method. Then, by following the least squares method (8), the relationships between cation exchange capacity, as the dependent variable, and the following independent variables were worked out: percentage of particles smaller than $0.002 \mathrm{~mm}$., percentage of particles smaller than $0.002 \mathrm{~mm}$. and percentage of organic matter, and summation of the percentage of particles smaller than $0.002 \mathrm{~mm}$. and those ranging between 0.05 and $0.002 \mathrm{~mm}$. The data were submitted to analysis of variance and the correlation coefficient and the coefficient of determination were then calculated.

\section{RESULTS AND DISCUSSION}

The summary of the statistical interpretation of the data is shown in table 1. In equation 1 a direct relationship between cation exchange capacity and percentage of particles smaller than $0.002 \mathrm{~mm}$. in size is evident. However, the correlation coefficient is nearly 0.44 and only 19 percent of the variability in exchange capacity can be explained on the basis of the percentage of particles smaller than $0.002 \mathrm{~mm}$.

Attempts further to explain a larger proportion of the variability in terms of other soil properties failed. When the percentage of particles between 0.05 and $0.002 \mathrm{~mm}$. as included in the equation, the proportion of the variability which could be explained raised to only 21 percent. When organic matter was included as the second independent variable, only 22 percent of the variability in cation exchange capacity could be explained. Thus, none of these equations provide a satisfactory mathematical basis for explaining the measured variations. 
It is evident that on a soil system, as it occurs in nature, variations in cation exchange capacity are not easily explained. However, in some perfect colloido-chemical systems variations in cation exchange attributable to variations in particle size can be measured under laboratory conditions. Harmon and Fraulini (5) and Grim and Bray (4) have shown this relationship for kaolinite and illite, respectively. However, in the case of montmorillonite, the situation has been different. Hauser and Reed (6) have shown that the cation exchange of montmorillonite does not change substantially with particle size variations within the range of 87 to $14 \mathrm{m \mu}$. Caldwell and Marshall (1) found no variation in the cation exchange capacity of nontronite within the 2 to $0.05 \mu$. They further report a slight increase for attapulgite as particle size decreased.

The soils of the Lajas Valley Area used in working out the relationships

Table 1.-Summary of the statistical altempts to correlale cation exchange capacily with particle size and organic matter conlent

\begin{tabular}{|c|c|c|}
\hline Functional relationship & $\begin{array}{r}\text { Coefficient of } \\
\text { determination }\end{array}$ & $\begin{array}{l}\text { Correlation } \\
\text { coefficient }\end{array}$ \\
\hline $\begin{array}{l}\text { (1) } Y=22.70+0.3147 \text { (percentage of particles smaller } \\
\text { than } 0.002 \mathrm{~mm} \text {.) }\end{array}$ & 0.19 & 0.44 \\
\hline $\begin{array}{l}\text { (2) } Y=20.99+2.400 \text { (percentage of organic matter) }+ \\
0.3103 \text { (percentage of particles smaller than } 0.002 \mathrm{~mm} \text { ) }\end{array}$ & .22 & .47 \\
\hline $\begin{array}{l}\text { (3) } Y=10.81+0.3486 \text { (summation of percentage of parti- } \\
\text { cles smaller than } 0.05 \text { and } 0.002 \mathrm{~mm} \text {.) }\end{array}$ & .21 & .46 \\
\hline
\end{tabular}

reported in this paper are montmorillonitic in nature. While in the case of kaolinite and illite, exchange can be mainly attributed to broken bonds, in montmorillonite and other expanding-lattice clay minerals it seems that particle size makes little difference. Here most of the exchange occurs on basal plane surfaces. According to Grim (3) moderate variation in cation exchange capacity can be expected with decreasing particle size since the main cause of cation exchange capacity in montmorillonite is substitution within the lattice structure.

\section{SUMMARY}

A study is herein reported where attempts to explain the variability in the cation exchange capacity of Lajas Valley soils in terms of other soil properties were made. The independent variables considered were percentage of particles smaller than $0.002 \mathrm{~mm}$., percentage of organic matter, and the summation of the percentage of particles ranging from 0.05 to $0.002 \mathrm{~mm}$. and smaller than $0.002 \mathrm{~mm}$. The correlation coefficients obtained were $0.44,0.47$ and 0.46 for each respective attempt. Only 19 percent of 
the variability in cation exchange capacity could be explained on the basis of the percentage of particles smaller than $0.002 \mathrm{~mm}$. in size. Another simple correlation where the percentage of particles between $0.05 \mathrm{~mm}$. and $0.002 \mathrm{~mm}$. was added to the percentage of particles smaller than $\mathbf{0 . 0 0 2}$ failed to explain satisfactorily any significant additional variability. A multiple correlation including the percentage of organic matter, in addition to the percentage of particles smaller than $0.002 \mathrm{~mm}$. also failed to explain any significant additional variability.

This failure is analyzed in view of the different nature of montmorillonitic clays that predominate in Lajas Valley soils.

\section{RESUMEN}

Se informa aquí un estudio en el que se intentó explicar la variabilidad en la capacidad de intercambio de cationes de los suelos del Valle de Lajas, usando como criterio otras propiedades del suelo. Las variables independientes que se consideraron fueron el porcentaje de partículas menores de $0.002 \mathrm{~mm}$., el porcentaje de materia orgánica y la suma del porcentaje de partículas que fluctuaban en tamaño entre 0.05 y $0.002 \mathrm{~mm}$. con las menores de $0.002 \mathrm{~mm}$. Se obtuvieron coeficientes de correlación de 0.44 , 0.47 y 0.46 en cada caso, respectivamente. Śblo el 19 por ciento de la variabilidad en la capacidad de intercambio de cationes pudo explicarse a base del porcentaje de partículas menores de $0.002 \mathrm{~mm}$. Por medio de otra correlación sencilla en la que se sumó el porcentaje de partículas entre 0.05 y $0.002 \mathrm{~mm}$. al de aquéllas menores de $0.002 \mathrm{~mm}$. tampoco pudo explicarse variabilidad alguna adicional de magnitud significativa. La correlación múltiple en que se consideró el porcentaje de materia orgánica en adición al de partículas menores de $0.002 \mathrm{~mm}$., tampoco permitió explicar una variabilidad adicional.

Esta falla se explica en vista de la naturaleza distinta de las arcillas del tipo montmorilonítico que predominan en los suelos del Valle de Lajas.

\section{LITERATURE CITED}

1. Caldwell, O. G., and Marshall, C. E., A study of some chemical and physical properties of the clay minerals montronite, attapulgite, and saponite, Bull. 354, Missouri Agr. Exp. Str. Res., 1942.

2. Carter, Oliver R., Soil survey of the Lajas Valley Area, USDA Soil Conservation Service in cooperation with Univ. P. R. Agr. Expt. Sta., Series 1961 (23) 1965.

3. Grim, R. E., Clay mineralogy, McGraw-Hill Book Co., Inc., New York, pp. 127-60, 1953.

4. Grim, R. E., and Bray, R. H., The mineral constitution of various ceramic clays, J. Amer. Ceram. Soc. 19: 307-15, 1936.

5. Harmon, C. G., and Fraulini, F., Properties of kaolinite as a function of its particle size, J. Amer. Ceram. Soc. 28: 252-58, 1940. 
6. Hauser, E., and Reed, C. E., Studies in thixotropy, II, The thixotropic behavior and structure of bentonite, J. Phys. Chem. 48: 911-34, 1937.

7. Lugo-López, M. A., Pérez-Escolar, R., Acevedo, G., and Juárez, Jr., J., Nature and properties of major soils of Lajas Valley, Bull.149, Agr. Expt. Sta., Univ. P.R. 1959.

8. Pearson, F. A., and Bennet, K. R., Statistical methods, John Wiley and Sons, Inc., New York, N. Y., 1942. 